\title{
Challenges for Improving Agricultural Resilience in the Context of Sustainability and Rural Development
}

\section{Wyzwania dla poprawy resilencji w rolnictwie w kontekście zrównoważonego rozwoju i rozwoju obszarów wiejskich}

\author{
Mangirdas Morkunas ${ }^{\star 1}$, Agnė Žičkienė ${ }^{* *}$, Tomas Baležentis ${ }^{* * 2}$ \\ Artiom Volkov ${ }^{* *}$, Dalia Štreimikienè $\dot{x}^{* *}$, Erika Ribašauskiené $\dot{x}^{\star *}$ \\ *Vilnius University, Faculty of Economics and Business Administration, \\ Sauletekio Av 9, Vilnius, Lithuania \\ ${ }^{1}$ E-mail: mangirdas.morkunas@evaf.vu.lt \\ **Lithuanian Centre for Social Sciences, Vivulskio str. 4A-13, Vilnius, Lithuania \\ ${ }^{2}$ E-mail (Correspondence Author): tomas.balezentis@laei.lt
}

\begin{abstract}
Research on economic resilience in agriculture is quite complicated due to the interdisciplinary nature of the notion. In agricultural, climate change, sustainability and food security research it appears as an endogenous phenomenon rather as the main one. This study aims to contribute to conceptualization of economic resilience in agriculture, revealing current and identifying future research directions. Bibliometric analysis supplemented with a literature overview serve this purpose. Results confirm the ambiguity and immaturity of economic resilience concept and its secondary position within overall agricultural resilience research framework.
\end{abstract}

Key words: economic resilience, agriculture, citation-based analysis, mapping

\section{Streszczenie}

Badania resilencji ekonomicznej w rolnictwie są dość skomplikowane ze względu na interdyscyplinarny charakter tego pojęcia. W badaniach dotyczących rolnictwa, zmian klimatycznych, zrównoważonego rozwoju i bezpieczeństwa żywności wydaje się, że jest to zjawisko endogeniczne, a nie główne. Niniejsze opracowanie ma na celu przyczynienie się do konceptualizacji resilencji ekonomicznej w rolnictwie, wskazując na obecne i identyfikując przyszłe kierunki badawcze. Służy temu analiza bibliometryczna uzupełniona przeglądem literatury. Wyniki potwierdzają niejednoznaczność i niedojrzałość koncepcji resilencji ekonomicznej oraz jej drugorzędną pozycję w ogólnych ramach badań resilencji rolnictwa.

Słowa kluczowe: ekonomiczna resilencja, rolnictwo, badania oparte na cytowaniach, mapowanie

\section{Introduction}

The high exposure of agricultural production to various types of risks in connection with the particularities of agricultural markets requires dedicated support policy measures on a wider scale. Recently, the global pandemic of COVID-19 showed a number of undesirable outcomes that once again stressed the need for reconsidering the resilience of food systems (Kumar et al., 2021).
Research on agricultural economic resilience, however, is scarce and fragmented. To systematize the existing knowledge and usage in the area a bibliometric analysis would be an important step forward to operationalizing the concept and applying resilience framework to agriculture. To the best of our knowledge, despite the fuzziness no such kind of analysis has been carried out on the concept of agricultural economic resilience. Therefore, our aim is to perform a bibliometric analysis, systematize the 
body of knowledge in the area and identify gaps for future research.

This paper extends the discussion on agricultural resilience that has become especially important amid the global interruptions of the supply chains due to the pandemic. An earlier paper (Žičkienè et al., 2020) looked into the role of farmer's behavior in the context of agricultural resilience and, thus, was confined to a narrower issue. The present paper applies the scientometric approach and furthers the discussion on agricultural resilience by taking a much wider approach and exploring the whole body of literature on the topic and its relationships with the other disciplines. Thus, this paper provides the overview of the state-of-the-art research in agricultural resilience and draws recommendations for further analysis.

The paper is structured as follows: Section 2 discusses the theoretical background of the agricultural resilience research. Section 3 presents the analytical approach taken. Section 4 presents the main findings. Finally, Section 5 concludes and identifies future research directions.

\section{Theoretical preliminaries}

\section{The concept of resilience}

The resilience concept in the articles reviewed is used quite loosely. Many researchers (Pearson, 2010; Lin, 2011; Altieri et al., 2015) ground their resilience concept on the definition of Holling (1973) and Folke et al. (2010), which refers to resilience as the propensity of a system to retain its organizational structure, feedbacks and functions following a perturbation. Pretty (2008) defines resilience quite similarly - as the capacity of a system to buffer shocks and stresses. Bernues et al. (2011) refer to resilience as a narrower concept defining it as the short-term capacity to return to a state of equilibrium and maintain functionality when the system is confronted with a strong punctual perturbation and opposes it to adaptive capacity which reflects system's flexibility to face long-term modifications.

Some researchers do not provide a clear definition of resilience concept used in the papers and its meaning may only be inferred from the context. Many of them (Challinor, 2007; Darnhofer, Fairweather and Moller, 2010) link resilience to system's adaptive capacities, which is defined as the capacity to reduce potentially negative effects of various perturbations either withstanding or recovering from them. Altieri and Nicholls (2013) refer to adaptive capacity as the set of social and agro-ecological preconditions that enable individuals or groups and their farms to respond to a perturbation in a resilient manner. Reidsma et al. (2010) do not explicitly use resilience concept, but similarly use the notion of adaptive capacity. In their work the adaptive capacity concept is expanded to include not only moderation of potential damages and coping with its consequences, but also taking advantage of emerging opportunities. Thompson and Scoones (2009) and Waage and Mumford (2008) differentiate between resilience and robustness (resistance) however does not provide a clear definition of neither of them.

Giannakis and Brugemann (2015) present a review of resilience definitions used in regional resilience academic area (based on Martin and Sunley (2015), where there are three distinct approaches used: engineering, ecological and evolutionary. The engineering based concept of resilience focuses on the resistance of a system to perturbations and its ability to bounce-back to the pre-shock equilibrium. The ecological concept refers to resilience as a system's ability to keep its structure and feedbacks before moving into a new equilibrium state in the face of a shock. The evolutionary approach treats resilience as a capacity of a system to withstand the perturbation, recover from it or even bounce-forward, that is, to respond to shocks by adaptation, adaptability and transformation (Pike et al. 2010 cited from Giannakis et al. (2015). These three approaches encompass all of the above mentioned definitions of resilience.

Relationships between resilience, vulnerability and sustainability

In the literature analyzed the concepts of resilience, vulnerability and sustainability are very much interwoven and sometimes not easily distinguished. Researchers treat these phenomena either as complementary, or as opposite, or as part of each other. For example, Pretty (2008) refers to resilience as a part of sustainability, which also incorporates persistence (the capacity of systems to continue over long periods). Darnhofer, Fairweather and Moller (2010) propose that resilience offers a vision of sustainability, Altieri and Nicholls (2013) state that resilience is a necessary but not sufficient condition of sustainability. Tendall et al. (2015) refers to resilience and sustainability as complementary concepts. Giannakis and Bruggeman (2015), who analyze resilience of regions and represent resilience approaches coming from economic geography, treat resilience as a separate construct without discussing the linkages between resilience and sustainability.

In some studies resilience concept is closely related to vulnerability. Altieri et al. (2015) argue that resilience (referred to as a response capacity) together with vulnerability and threat determine the risk of negative impact. Schilling et al.(2012) state that vulnerability encompasses exposure, sensitivity and adaptive capacity. This adaptive capacity, although not directly referred to as resilience, can be understood as namely this phenomenon, so in such a case resilience would a part of vulnerability. Schilling et al. (2012), based on IPCC (2007), distinguish between generic and impact specific adaptive capacities. Simelton et al. (2009) however treat resilience as an opposite of vulnerability, i.e. low-vulnerability cases are viewed as resilient cases. 


\section{Determinants of resilience}

The question of what increases (or inhibits) resilience is one of the most relevant issues prevailing in academic discussion in the resilience framework. In almost every article under our scope this question is being analyzed, albeit the depth and width of its scrutiny differs significantly.

A variety of ways and methods have been proposed to increase resilience by different authors, comprising a wide range of forms (managerial, technical and financial), scales (local, regional and global) and actors (farmers, industries and governments) (Reidsma et al., 2010). However, the most important factors nurturing resilience surprisingly overlap in a majority of studies. Darnhofer, Fairweather and Moller (2010) cite Folke et al. (2003) and Berkes (2007) to list four temporarily and spatially interacting groups of factors promoting resilience in social-ecological systems: (1) learning to live with change and uncertainty; (2) creating opportunity for self-organization and cross-scale linkages; (3) nurturing diversity in its various forms; and (4) combining different types of knowledge and learning. The latter three factors have been emphasized in a number of studies. Challinor et al. (2007) argue that farmers' abilities to cope with and adapt to climate change significantly depend on their access to relevant knowledge and information as well as on building relevant social networks. Darnhofer, Fairweather and Moller (2010) and Bernues et al. (2011) state that learning through experimentation and monitoring and a diversity of resources, production processes and products allow farmers to better cope with various perturbations. Chagnon et al. (2015), presenting a specialized study of insecticides' usage and ecosystems, argue that diversity is of key importance on ecosystem functioning. Lin (2011) and Altieri et al. (2015) propose that crop diversification is an effective method to improve resilience of agroecosystems. According to Lin (2011), crop diversification can improve resilience in a number of ways: by strengthening abilities to suppress pest outbreaks, dampening pathogen transmission, and by buffering crop production from the effects of negative meteorological events. Diversity creates conditions for redundancy. And redundancy is of paramount importance when some sort of changes occur, since it enables the continuance of the system functioning and provision of its key services. In the other study Altieri and Nicholls (2013) also add that social capital and social organization strategies used collectively by farmers in order to cope with the difficult circumstances are core elements of resilience. Giannakis (2015) basis his research on theoretical and practical findings that at a macro level (regional economy) the resilience is determined by several factors, such as the sectoral composition of the economy (especially its diversity), the skills of the workforce, the innovation rate, the connectivity and the institutional arrangements within regions.
Summarizing, the main determinants of resilience, as cited by the majority of researchers and confirmed by a number of theoretical and practical research findings, can be grouped into these categories:

1. Encouraging learning and acquisition of skills and granting access to relevant information and knowledge.

2. Combining different types of knowledge and stimulating innovations.

3. Nurturing diversity in its various forms at various spatial and temporal levels.

4. Creating opportunities for self-organization, intra and inter-scale linkages.

Types of resilience

In the literature there are two types of resilience researched: specified and general resilience. Specified resilience refers to the resilience of what, to what (e.g., the resilience of pig farming to classical swine fever) (Biggs et al., 2012). Whereas general resilience does not deal with any particular shock or particular aspect of the system that might be affected by that shock, but rather considers general system characteristics and capabilities that allow better reaction to various kinds of shocks and perturbations (Martin and Sunley, 2015). Resilience to a specific disturbance or event involves identifying a particular threshold effect such that the system will not recover to the same levels of performance or its earlier pattern of behavior if this threshold is crossed (Resilience Alliance, 2010). It is very important to make a distinction between these two kinds of resilience, because increasing resilience to some particular kind(s) of perturbations may lead to declining resilience to other types of disturbances. For example, if system redundancy is traded off to build resilience to one specific type of disturbance, then the system's capacity to cope with unexpected or completely novel challenges may be diminished (Resilience Alliance, 2010).

Most of the articles analyzed in this paper focus on specified resilience with a frequent focus on namely resilience to climate change and the disturbances related to it. Lin (2011) studies how diversification in agricultural systems can increase resilience of farmers under climate change. Challinor et al. (2007) assess the vulnerability of food crop systems in Africa to climate change. Reidsma et al. (2010) synthesizes results from a number of empirical analyses on the role of adaptation under climatic change and extends the findings by providing the insights on the adaptation of farmers and regions in the European Union to prevailing climatic conditions, climate change and climate variability in the context of other conditions and changes. Altieri et al. in both articles (Altieri and Nicholls 2013) and (Altieri et al. 2015) also analyze resilience to changing climate focusing on how traditional agricultural practices increase resilience and how to design climate change-resilient farming systems. Falloon and Betts (2010) in the similar vein in- 
vestigate potential impacts of climate change on agricultural adaptation and vice versa. A different line of analysis comes from Darnhofer, Fairweather and Moller (2010) who focus on general resilience of farmers. Similarly, Bernues et al. (2011) discusses critical points of sustainability and resilience of pasture-based livestock farming systems in the context of diverse socio-economic, political and environmental scenarios. Giannakis and Bruggeman (2015), although focusing their analysis on a meso-macro level, also research general resilience, investigating the processes through which the impacts of the recessionary shocks can be diffused to local economies through the linkages and interdependences between economic sectors with an example of Greece.

\section{The context of research}

Articles most cited in relation to economic resilience of agriculture is spread across various fields of research, however only a part of articles directly deal with economic resilience. Simelton et al. (2009), Lin (2010) and Altieri et al. (2015) focus precisely on resilience of farming systems. Simelton et al. identify socio-economic indicators associated with crop sensitivity and resilience to drought. Lin (2011) discusses how crop diversification can increase resilience in agriculture. Altieri et al. (2015) present a conceptual framework to assess the resilience of farming systems and some methodological attempts to assess it. Tendall et al. (2015) create a conceptual framework of food system resilience. Darnhofer, Fairweather and Moller (2010) show how resilience theory applied to farming may provide a more comprehensive route to achieving sustainability and offers rules of thumb as guides to building farm resilience. However, a large share of publications comes from the research on sustainability where resilience is mentioned only in relation to sustainability (Pretty 2008, Bernues et al. 2011). Other authors discuss resilience in the context of vulnerability and adaptation to climate change (Challinor et al. 2007, Reidsma et al. 2010, Smith and Olesen 2010, Schilling et al. 2012). Yet the largest share of publications addresses resilience of agriculture indirectly (Kollner and Scholz, 2008; Waage and Mumford, 2008; Thompson and Scoones, 2009, Chagnon et al., 2015) while analyzing other issues. The resilience concept in these articles is used only sparingly and fragmentally.

\section{COVID-19 pandemic and agricultural resilience}

In the last two years a very large amount of research was dedicated to the COVID-19 pandemic and its impact on agriculture, where resilience and vulnerability were the two main perspectives approaching this theme. All the dimensions of resilience have been tackled in various studies: robustness or absorptive capacity (Galanakis, 2020; Zarei \& Rad, 2020), adaptability (Adnan \& Nordin, 2020; Henry,
2020; Cattivelli \& Rusciano, 2020; Zimmerer \& de Haan, 2020) and transformability (Boughton et al., 2020; Petetin, 2020; Timilsina et al., 2020). However, usually researchers approach only one of the dimensions in their studies and the possible interactions among the dimensions are left behind. In general, the literature on COVID19 pandemic and agricultural resilience is focused more on the negative effects of pandemic rather than on theoretical grounds of resilience. Consequently, resilience concept is again used quite loosely, often reflecting an intuitive meaning of the concept, without its clear definition.

The analysis of the literature of COVID-19 pandemics and agricultural resilience showed that most attention was dedicated to the food supply chains (Sharma et al., 2020; Farell et al., 2020; Worstell, 2020; Bene, 2020; Boyaci-Gündüz et al., 2021; Thilmany et al., 2021). Which is not surprising, since one of the main negative impacts of the pandemics was related to the closure of borders which resulted in unprecedented strain on supply chains (Kerr, 2020). Subsequently ones of the most popular research topics were food security (Bene, 2020; Clapp \& Moseley, 2020; Boyaci-Gündüz et al., 2021) and labor supply (Anderson et al., 2020; Ridley \& Devadoss, 2021) - vital aspects of food supply chains that were directly affected by the pandemic. In general, it's being predicted that the impact of COVID-19 on agriculture and global food security will be complex (Torero, 2020), and many of the consequences are not yet identified (Jámbor et al., 2020).

A number of studies have presented various ways and measures for the mitigation of crisis and enhancement of agri-food systems' adaptability in the future. For example, Timilsina et al. (2020) propose, that government should take vigorous steps to facilitate farmers using automated machinery facilities; enhancing quality of seeds and fertilizers; provide direct financial funding for vulnerable farmers to build agricultural sector resilience to the pandemic. Lioutas and Charatsari (2021) discuss three potential mechanisms that can mitigate the impacts of major crises in agriculture: resilience-promoting policies, community marketing schemes, and smart farming technology. Worstell (2020) attempts to examine the eight qualities (Connectivity, Local self-organization, Innovation, Maintenance/redundancy, Accumulation of value-added infrastructure, Transformation, Ecological integration, Diversity) proposed as necessary for resilient food systems in the CLIMATED model (Worstell \& Green, 2017) and how broadly these qualities apply in COVID-19 scenario. All these studies show that COVID-19 crisis has boosted a large interest in the resilience of agri-food systems. A lot of empirical studies has been performed on the issue, however theoretical discussion on namely resilience phenomenon in agricultural sector at various levels is still lacking. 


\section{Methods}

The data was retrieved on $30^{\text {th }}$ of November 2020 . The Clarivate Analytics Web of Science Core collection was chosen for the data mining. It guarantees the high standards of scientific integrity, as journals indexed in CA WoS are considered to apply one of the most formidable standards for a peer review process (Da Silva \& Marmon, 2017). The time period for the data analysis covered years 1990-2020. The selected keywords were economic AND resilience AND agriculture. The search provided 668 documents. The initial set inclusion and exclusion criteria are presented in Table 1.

Table 1. Inclusion and exclusion criteria for the analysis.

\begin{tabular}{|l|l|}
\hline Inclusion criteria & Exclusion criteria \\
\hline Paper in English & $\begin{array}{l}\text { Paper in other, not Eng- } \\
\text { lish language }\end{array}$ \\
\hline Paper has abstract & $\begin{array}{l}\text { Paper does not have an } \\
\text { abstract }\end{array}$ \\
\hline Paper provide keywords & $\begin{array}{l}\text { Document does not pro- } \\
\text { vide keywords }\end{array}$ \\
\hline $\begin{array}{l}\text { Document type: article, } \\
\text { early access, conference } \\
\text { material, book chapter, } \\
\text { editorial, review. }\end{array}$ & $\begin{array}{l}\text { Document type: commu- } \\
\text { nication, technical report, } \\
\text { etc. }\end{array}$ \\
\hline
\end{tabular}

The rationale for setting the inclusion and exclusion criteria is the following. Authors are usually not familiar with other than English and their native languages, so they would not be capable to critically assess and evaluate papers prepared in other languages. Bibliometric clustering techniques use abstract and keywords for the analysis. Papers without keywords cannot be properly processed, so must be excluded. The selection of document type is important due to the fact, that typically communication or technical reports are not obliged to follow rigorous peer-review procedures (van Raan, 1996). In order to avoid compromising research integrity we decided to avoid such types of papers. Despite the above-mentioned standards, we found all extracted documents satisfying the criteria to be included into the analysis.

The data was processed using VOSviewer 1.16.5 software. The selected tool is used quite frequently in business and economics research (Ferreira, 2018; Davlembayeva, Papagiannidis \& Alamanos, 2019; Piñeiro-Chousa et al., 2020; Haque, Ahmad, \& Azad, 2020). It is aimed at analyzing large numbers of bibliometric information required for conceptualizing the researched notions (Rosas, 2017), indicating prevailing theoretical streams (Findlay, 2017) or outlining future research directions (Proctor, 2019). This method is highly praised when researching notions, attributed to a number scientific fields ( $\mathrm{Hu} \&$ Zhang, 2017) or considered to be of an interdisciplinary nature (MacLeod, M \& Nagatsu, 2018). These insights confirm the suitability of selected research method, as economic resilience in agriculture covers not only agricultural (Michler et al., 2019) or economical (Giannakis \& Bruggeman, 2020) but also environmental (Lipper et al., 2017) and managerial (Di Gregorio, 2017) aspects and can be attributed to various disciplines. For this purpose, we apply four techniques of bibliometric clustering: 1) a bibliographic clustering of publications in economic resilience in agriculture; 2) a co-citation analysis of scientific documents and publication sources in a researched field; 3 ) co-occurrence of keywords and 4) co-authorship analysis on institutional and country levels.

\section{Results and discussion}

Figure 1 clearly indicates, that the turning point in the development of research on economic resilience in agriculture is 2004. This year may serve as a threshold for researchers conducting literature review, as it is noted, that after 2004 research on economic resilience in agriculture started gaining momentum and was extrapolated to other disciplines, such as sustainability (Perrings, 2006), water management (2004), assessment of institutional quality (Jayararnan, 2004), adaptive management practices (Lin, 2011), environmental risk and natural resources management (Deshingkar, 2012) or even to a political context (Meitzner, 2010).

In order to reveal the most influential publications on economic resilience in agriculture, we arranged them according to the number of citations (Table 2). Analyzing most cited publications on economic resilience in agriculture we noticed a few interconnected theoretical sprouts. Economic resilience in agriculture has been often researched through the lens of sustainability concept (Pretty, 2008; Bernues et al., 2011; Darnhofer et al., 2010). The highest number of the most cited publications in agricultural economic resilience focus on the adaptation and mitigation of climate change challenges to agriculture (Lin, 2011; Reidsma et al., 2010; Challinor et al., 2007; Smith \& Olesen, 2010; Falloon \& Bets, 2010; Altieri et al., 2015; Schilling et al., 2012; Altieri \& Nichols, 2017). Economic resilience in agriculture was also investigated under environmental research umbrella (Waage \& Mumford, 2008; Koellner \& Scholz, 2008; Grau, Kuemmerle \& Macchi, 2013; Rodrigues et al., 2011; Chagnon et al., 2015). Smaller literature streams, which analyze economic resilience in agriculture are coupled around soil management practices (Simelton et al., 2009; Lal, 2016) and food systems research (Thompson \& Scoones, 2009; Tendall et al., 2015).

The most productive institutions in economic resilience of agriculture are presented in Table 3. The analysis of the most productive institutions on economic resilience in agriculture research domain in 1990-2020 revealed a quite high concentration of scientific activities, as almost $25 \%$ of all publications 
140

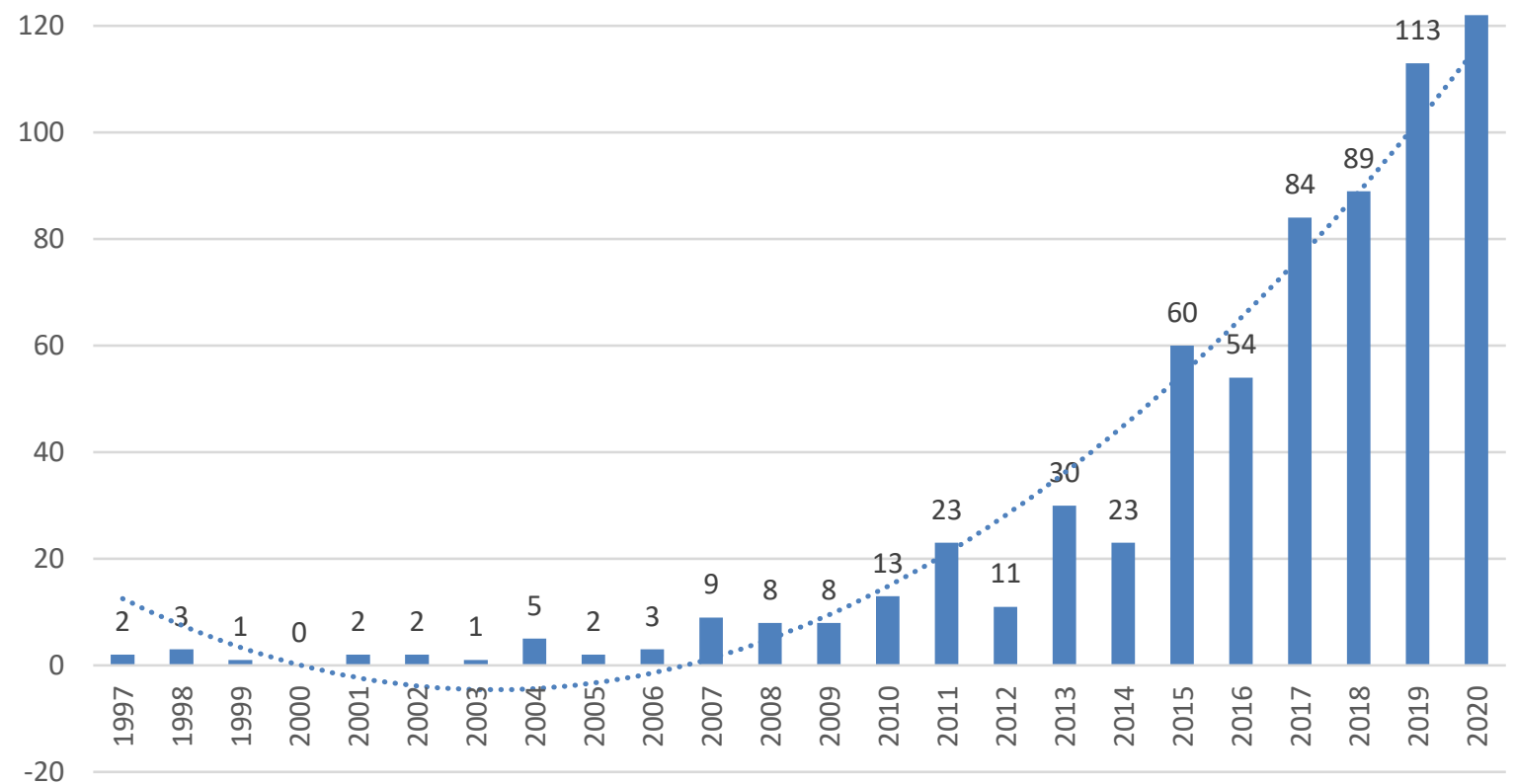

Figure 1. Number of scientific publications on economic resilience in agriculture in WoS DB in 1990-2020

Table 2. Most cited publications on economic resilience in agriculture

\begin{tabular}{|l|c|}
\hline Author(s) & Total times cited \\
\hline Pretty, J, 2008 & 641 \\
\hline Lin, BB, 2011 & 467 \\
\hline Reidsma et al., 2010 & 264 \\
\hline Challinor et al., 2007 & 249 \\
\hline Falloon \& Betts, 2010 & 225 \\
\hline Altieri et al., 2015 & 216 \\
\hline Rodrigues et al., 2011 & 193 \\
\hline Chagnon et al., 2015 & 174 \\
\hline Bernues et al., 2011 & 169 \\
\hline Smith \& Olesen, 2010 & 157 \\
\hline Darnhofer et al., 2010 & 149 \\
\hline Schilling et al., 2012 & 133 \\
\hline Grau et al., 2013 & 125 \\
\hline Altieri \& Nicholls, 2017 & 119 \\
\hline Simelton et al., 2009 & 133 \\
\hline Thompson \& Scoones, 2009 & 115 \\
\hline Waage \& Mumford, 2008 & 109 \\
\hline Tendall et al., 2015 & 105 \\
\hline Koellner \& Scholz, 2008 & 104 \\
\hline Lal, 2016 & 107 \\
\hline
\end{tabular}

on economic resilience in agriculture during the researched period was produced by 10 most productive institutions. These findings are consistent with Zorzetto et al. (2006) and Iaria, Schwarz \& Waldinger (2018) insights about the concentration of scientific production although they contradict to the overall trend of de-concentration in a World's scientometrics (Maisonobe et al., 2017). It is not preferable from the food security perspective either. As resilience of agriculture is considered to be essential for the food security in the World (Bene, 2020) and ag- ricultural output is very dependent on local conditions and agricultural practices employed (Singhal \& Vatta, 2017), the research on resilience in agriculture should be more dispersed and located in areas close to agricultural production (Busch \& Lacy, 2019).

Table 3. The most productive institutions in economic resilience in agriculture domain in 1990-2020

\begin{tabular}{|l|c|c|}
\hline Institution & $\begin{array}{c}\text { Number } \\
\text { of docu- } \\
\text { ments pu- } \\
\text { blished }\end{array}$ & $\begin{array}{c}\text { \% of total } \\
\text { publica- } \\
\text { tions }\end{array}$ \\
\hline CGIAR & 32 & $4,79 \%$ \\
\hline $\begin{array}{l}\text { University of California } \\
\text { System }\end{array}$ & 21 & $3,14 \%$ \\
\hline INRAE & 18 & $2,69 \%$ \\
\hline $\begin{array}{l}\text { United States Department } \\
\text { of Agriculture (USDA) }\end{array}$ & 16 & $2,40 \%$ \\
\hline $\begin{array}{l}\text { Commonwealth Scientific } \\
\text { Industrial Research Or- } \\
\text { ganisation (CSIRO) }\end{array}$ & 15 & $2,25 \%$ \\
\hline $\begin{array}{l}\text { Wageningen University } \\
\text { Research (WUR) }\end{array}$ & 15 & $2,25 \%$ \\
\hline $\begin{array}{l}\text { Indian Council of Agri- } \\
\text { cultural Research (ICAR) }\end{array}$ & 14 & $2,10 \%$ \\
\hline $\begin{array}{l}\text { Centre National de la Re- } \\
\text { cherche Scientifique } \\
\text { (CNRS) }\end{array}$ & 12 & $1,80 \%$ \\
\hline Alliance & 10 & $1,50 \%$ \\
\hline Helmholtz Association & 10 & $1,50 \%$ \\
\hline Total & $\mathbf{1 6 3}$ & $\mathbf{2 4 , 4 0 \%}$ \\
\hline
\end{tabular}

In order to better assess the geographical dispersion of research on economic resilience in agriculture, the countries were ranked according to the number of publications on economic resilience in agriculture 
domain (Table 4). The analysis revealed an unprecedented concentration of scientific publications of economic resilience in agriculture within 10 most productive countries, which account for more than $92 \%$ of all publications in the field. Such accumulation of knowledge in a small number of states creates unfavorable conditions for further knowledge acquisition and dissemination. It also may play a role in hindering increase in competition in production of agricultural goods, since even in the primary sector knowledge-based management practices tend to grant competitive advantage (Vasiljević \& Savić, 2013), thus making the achievement of convergence in agriculture even more complicated (Volkov et al., 2019).

Table 4. The most productive countries in economic resilience in agriculture domain in 1990-2020

\begin{tabular}{|c|c|c|}
\hline Country/Region & $\begin{array}{c}\text { Number of } \\
\text { documents } \\
\text { published }\end{array}$ & $\begin{array}{c}\text { \% of total } \\
\text { publications }\end{array}$ \\
\hline USA & 157 & $23,50 \%$ \\
\hline England & 81 & $12,13 \%$ \\
\hline Australia & 70 & $10,48 \%$ \\
\hline Germany & 59 & $8,83 \%$ \\
\hline Italy & 49 & $7,34 \%$ \\
\hline India & 47 & $7,04 \%$ \\
\hline P. R. of China & 42 & $6,29 \%$ \\
\hline France & 41 & $6,14 \%$ \\
\hline Spain & 41 & $6,14 \%$ \\
\hline South Africa & 30 & $4,49 \%$ \\
\hline Total & $\mathbf{6 1 7}$ & $\mathbf{9 2 , 3 7 \%}$ \\
\hline
\end{tabular}

The journal engaged into dissemination of research on economic resilience in agriculture are presented in Table 5. Among them, Sustainability is followed by Agricultural Systems with the number of relevant publications differing more than 3 times. Such disparity may be explained by the fact, that Sustainability is more interdisciplinary, in addition, resilience based studies are very often interconnected with sustainability framework, making an above mentioned publication source an ideal vehicle for the dissemination of research in a particular field. It is worth noticing, that only Agricultural Systems is a truly agricultural journal among the most productive publication sources in economic resilience in agricultural domain. Others journals focus on environmental issues (Environmental Research Letters, Regional Environmental Change, Environmental Science \& Policy, Ecology \& Society), policy (Land Use Policy, Journal of Rural Studies), or publish sustainability related issues (Sustainability, International Journal of Agricultural Sustainability, Agroecology and Sustainable Foods Systems). This fact once again confirms the interdisciplinary nature of economic resilience and reveals the shortage of its research in agricultural economics' domain.
Table 5. Journals with a highest number of publications on economic resilience in agriculture

\begin{tabular}{|l|l|l|l|}
\hline $\begin{array}{l}\text { Publication } \\
\text { Source }\end{array}$ & $\begin{array}{l}\text { Num- } \\
\text { ber of } \\
\text { publica- } \\
\text { tions }\end{array}$ & $\begin{array}{l}\text { \% of total } \\
\text { publica- } \\
\text { tions }\end{array}$ & $\begin{array}{l}\text { IF } \\
\mathbf{2 0 1 9}\end{array}$ \\
\hline Sustainability & 45 & $6,74 \%$ & 2.576 \\
\hline $\begin{array}{l}\text { Agricultural } \\
\text { Systems }\end{array}$ & 14 & $2,10 \%$ & 4.212 \\
\hline Land Use Policy & 13 & $1,95 \%$ & 3.682 \\
\hline $\begin{array}{l}\text { Journal of Rural } \\
\text { Studies }\end{array}$ & 12 & $1,80 \%$ & 3.544 \\
\hline $\begin{array}{l}\text { Environmental } \\
\text { Research Letters }\end{array}$ & 11 & $1,65 \%$ & 6.096 \\
\hline $\begin{array}{l}\text { Ecology and } \\
\text { Society }\end{array}$ & 10 & $1,50 \%$ & 3.89 \\
\hline $\begin{array}{l}\text { International } \\
\text { Journal of } \\
\text { Agricultural } \\
\text { Sustainability }\end{array}$ & 10 & $1,50 \%$ & 2.278 \\
\hline $\begin{array}{l}\text { Regional Environ- } \\
\text { mental Change }\end{array}$ & 9 & $1,35 \%$ & 3.481 \\
\hline $\begin{array}{l}\text { Agroecology and } \\
\text { Sustainable Foods } \\
\text { Systems }\end{array}$ & 8 & $1,20 \%$ & 1.636 \\
\hline $\begin{array}{l}\text { Environmental } \\
\text { Science \& Policy }\end{array}$ & 8 & $1,20 \%$ & 4.767 \\
\hline Total & $\mathbf{1 4 0}$ & $\mathbf{2 0 , 9 6 \%}$ & \\
\hline
\end{tabular}

\section{A bibliographic analysis of research on economic} resilience in agriculture

In order to reveal interconnectedness of scientific research in economic resilience in the field of agriculture, we conducted a bibliographic analysis. This method allows to identify the existing layers of the concept under investigation (Brandao et al., 2017) and enables to predict the future research directions of the scientific notion more precisely (Youngblood \& Lahti, 2018).

To investigate the reference relationships between different scientific documents researching economic resilience in the domain agriculture we employed a bibliographic coupling technique, which is a common tool in a bibliographic research (Habib \& Afzal, 2019). The preselected threshold for the document to be included into the analysis - no less than 25 citations.

Analyzing the results of bibliographic coupling, 8 distinct clusters can be identified (Fig. 2). The biggest and most influential network is dominated by Pretty's (2008) article. The total link strength is 72 in 45 links with 603 citations in total. Second the most influential network is centered around Lin's (2011) publication (blue cluster). The total link strength is 61 in 34 links and 460 citations. The most intensive although not of the highest importance in the development of agricultural resilience research is the violet cluster dominated by Altieri et al. (2015). It shows the highest total link strength among all clusters -84 in 37 links and 209 citations. The fourth most intensive is the red cluster, which is based 


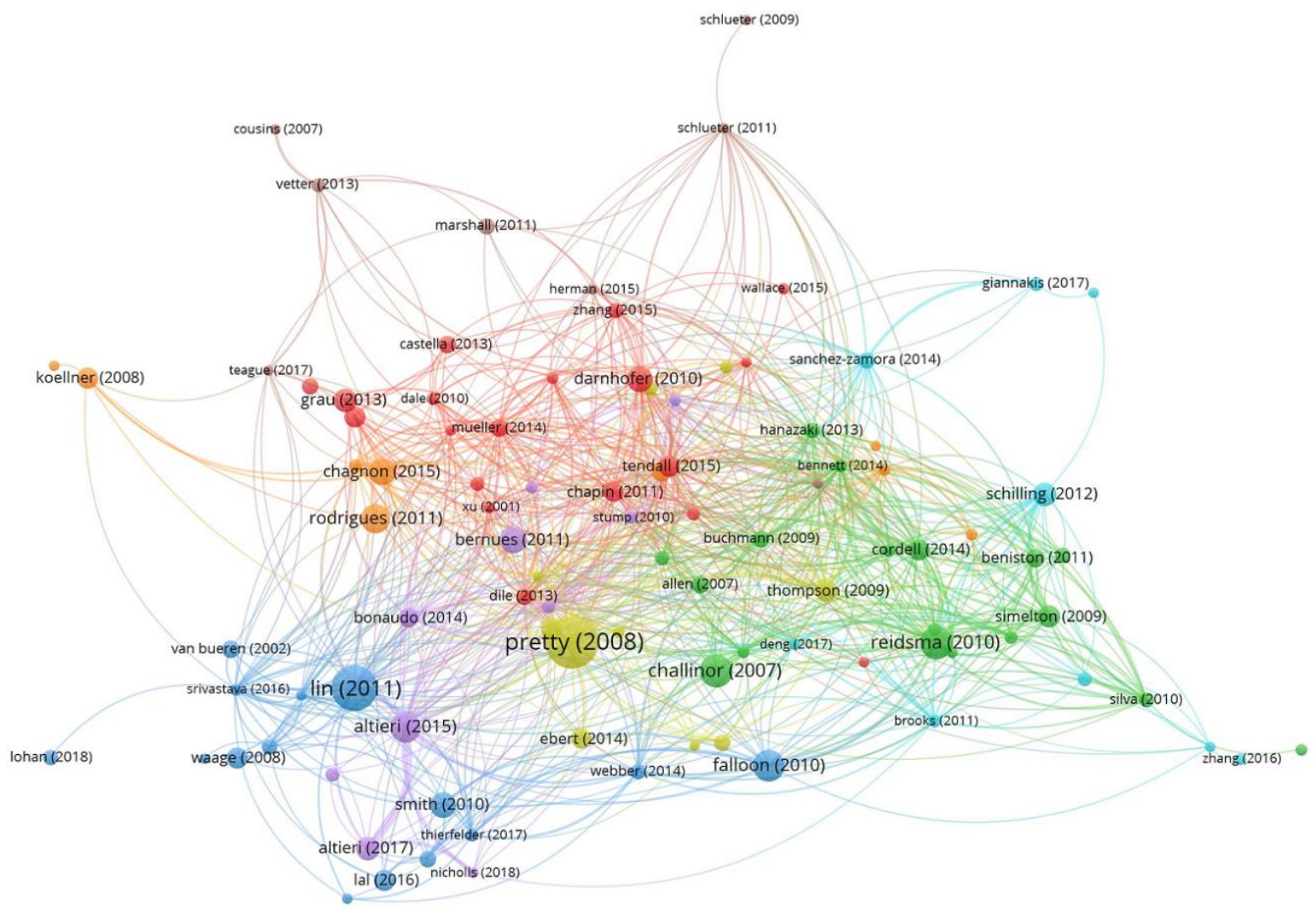

Figure 2. Co-citation coupling of publications, devoted to economic resilience in agriculture in 1990-2020

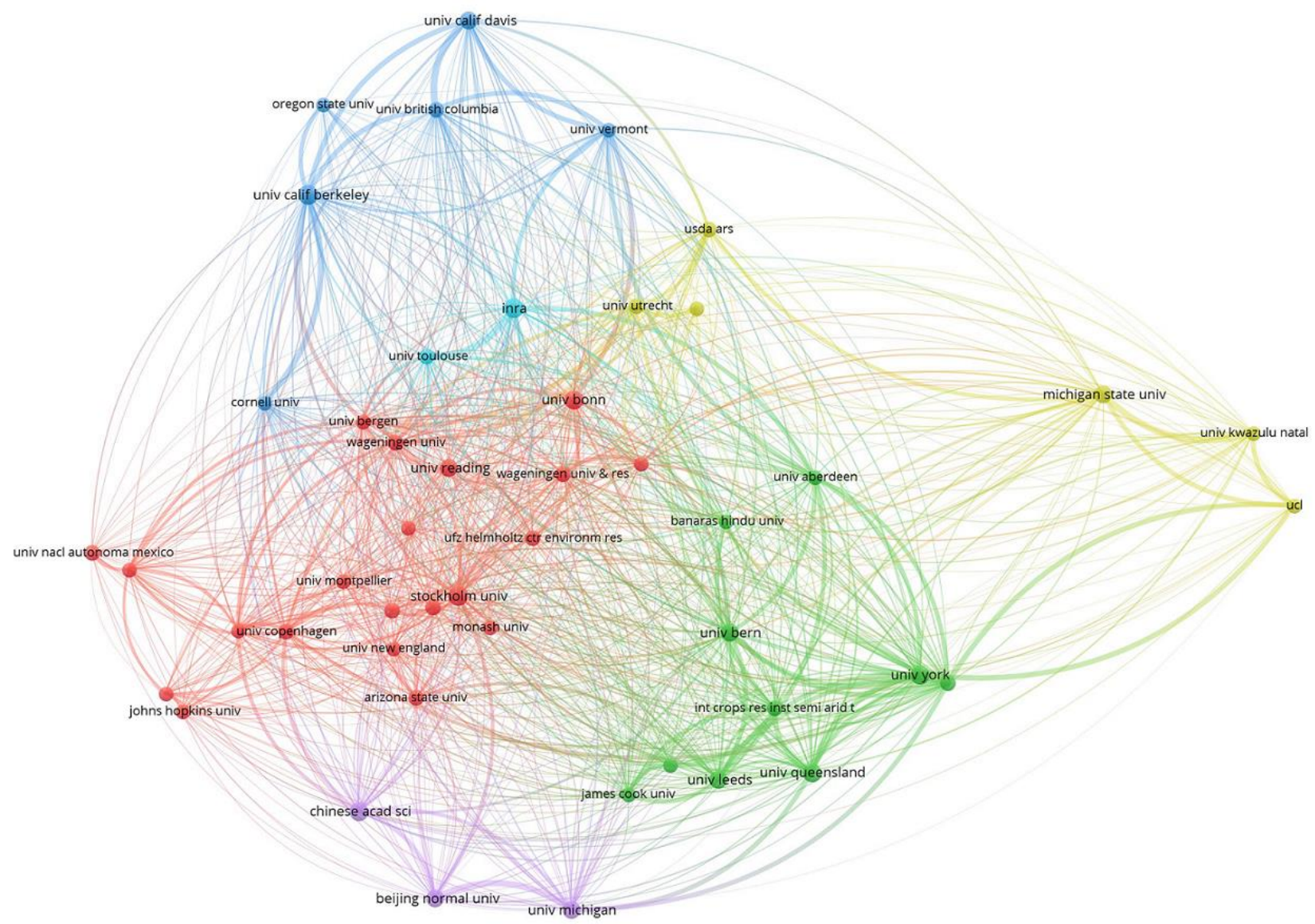

Figure 3. The most productive institutions in economic resilience in agriculture domain in 1990-2020 
around Darnhofer (2010). It shows a total link strength of 30, 51 link and a total number of citations -145 . The fifth cluster (the green one) is less polarized, showing two publications of a comparable importance - Challinor (2007) and Reidsma (2010), the latter being in a slightly more important position within the network with the total link strength of 47 in 22 links and 246 citations in related publications. It is worth noticing, that although the green network shows higher number of citations, its total link strength is lower indicating red cluster's higher thematic relatedness and interconnectedness, which presuppose a narrower and more specific research area compared to the green cluster. This is confirmed by a heat map analysis, showing more intense yellow color around red cluster publications. The sixth network (the light blue) is led by Schilling (2012) with a total link strength of 41 in 25 links and 129 citations. The least important are orange and brown clusters, networked around Chagnon (2015) and Schlueter (2011) with total link strength of 27,17 links, 126 citations and a total link strength of 29 in 22 links with 28 citations respectively. Heat map clearly indicates the higher importance of orange cluster in the development of research in economic resilience in agriculture due to its more integral position within the network and significantly brighter spots showing higher comparative weight of publications attributed to the orange cluster as compared to the brown one. The more or less clear boundaries can be drawn around red, green and brown clusters indicating distinctiveness and thematic proximity. Red cluster publications are more focused on a view on economic resilience within the sustainability framework, green network publications analyze the strategies on farmers' adaptation to climate change and, among them, the economic resilience phenomenon. Brown cluster analyze economic resilience from the socioeconomic perspective, analyzing socioeconomic consequences on rural population due to various environmental risks/disasters.

Further the investigation of the most productive institutions in the domain of economic resilience in agriculture was performed (Figure 3). Only institutions, which have produced no less than 5 publications in a researched field, are included into the analysis. The analysis confirms the Abankina Filatova \& Nikolayenko (2018) presumptions about quite separate research topics investigated in different scientific institutions. Oxford University can be considered as the most influential in promoting research on economic resilience in agriculture leading a green cluster of research institutions with a total link strength of 1536 (with 44 links provided only by 6 scientific publications). Other influential institutions lying within the green cluster encompass: University of York, Bern University, University of Queensland, Leeds University and University of Aberdeen. The second most influential cluster is led by University of California at Berkeley (blue network) with a total link strength of 1271 in 45 links with 9 documents on economic resilience in agriculture published. This network is composed solely of Northern American universities and includes University of California (Davis), Oregon State University, University of British Columbia, Cornell University and University of Vermont. The third one (red cluster) is led by the WUR, which in the analysis is represented by two separate institutions Wageningen University and Wageningen University \& Research. It is because till 2016 the research branch of Wageningen University was operating as a distinct institution. Further on, in order to better reveal the contribution of institutions, we analyze these two institutions as one entity. Subsequently its combined total link strength is 1249 with 47 links and 12 documents published. The fourth most important cluster is led by INRA (light blue) with a total link strength of 1001, 46 links and 9 documents published. It is the smallest cluster by number of participants represented only by the University of Toulouse. The fifth (violet color) cluster is led by the University of Michigan (total link strength - 913, 44 links and 7 publications published) followed also by a small number of institutions - Beijing Normal University and Chinese academy of science. The last (yellow) cluster is established around Michigan State University with a total link strength of 860, 41 link and 7 documents. Although network analysis put the red cluster only into the $3^{\text {rd }}$ place according to the influence in the development of research in economic resilience in agriculture, the heat map analysis clearly indicates the intensity, relative weight and a big number of institutions engaged into the research in the relevant area. So researchers interested in the topic should pay attention to the output of the institutions of the red cluster in the future. The small amount of overlapping plots in a density map also indicates a quite high distinctiveness of studies conducted by different institutions in this domain.

In order to reveal publication sources, most engaged in dissemination of knowledge of economic resilience in agriculture, we conducted a co-citation analysis of scientific journals (Fig. 4). The threshold to be included into analysis - no less than 5 published publications on economic resilience in agriculture. The network analysis revealed 5 distinct clusters. The biggest blue-colored cluster is led by the journal Agriculture, Ecosystems \& Environment (ISSN: 0167-8809) with a total link strength of 29744, 250 links and 533 citations. The second biggest (red color) network is clustered around the Global Environmental Change (ISSN: 0959-3780) scientific source. Its measured total link strength is 27727 , number of links - 253, total number of citations 725. Heat map analysis implicates much higher density of the red cluster, which means it is significantly less polarized compared to the blue one, so the knowledge gathering is dispersed among the higher number of scientific sources. It is worth noticing, 


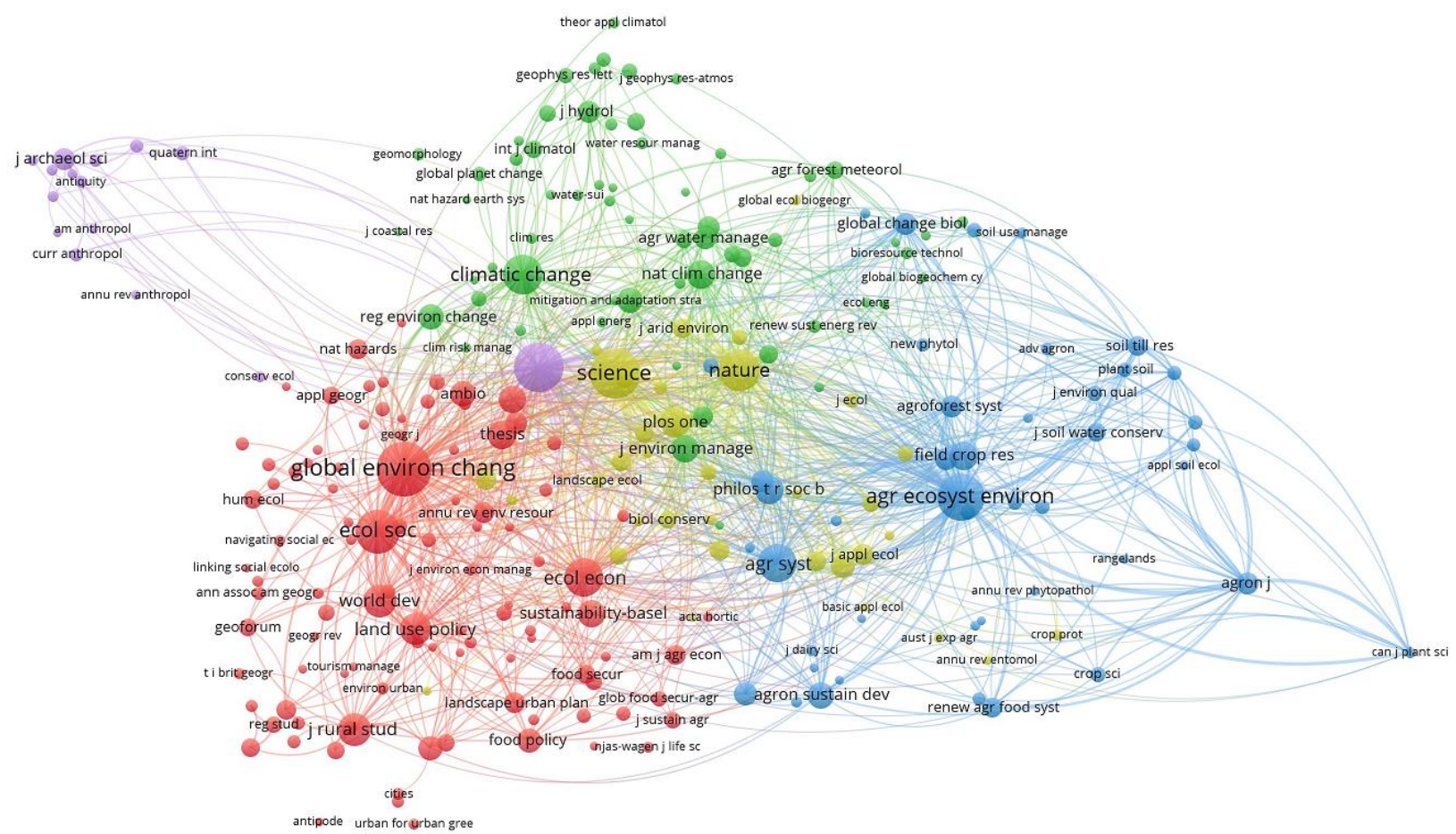

Figure 4. Co-citation analysis of publications sources on economic resilience in agriculture in 1990-2020

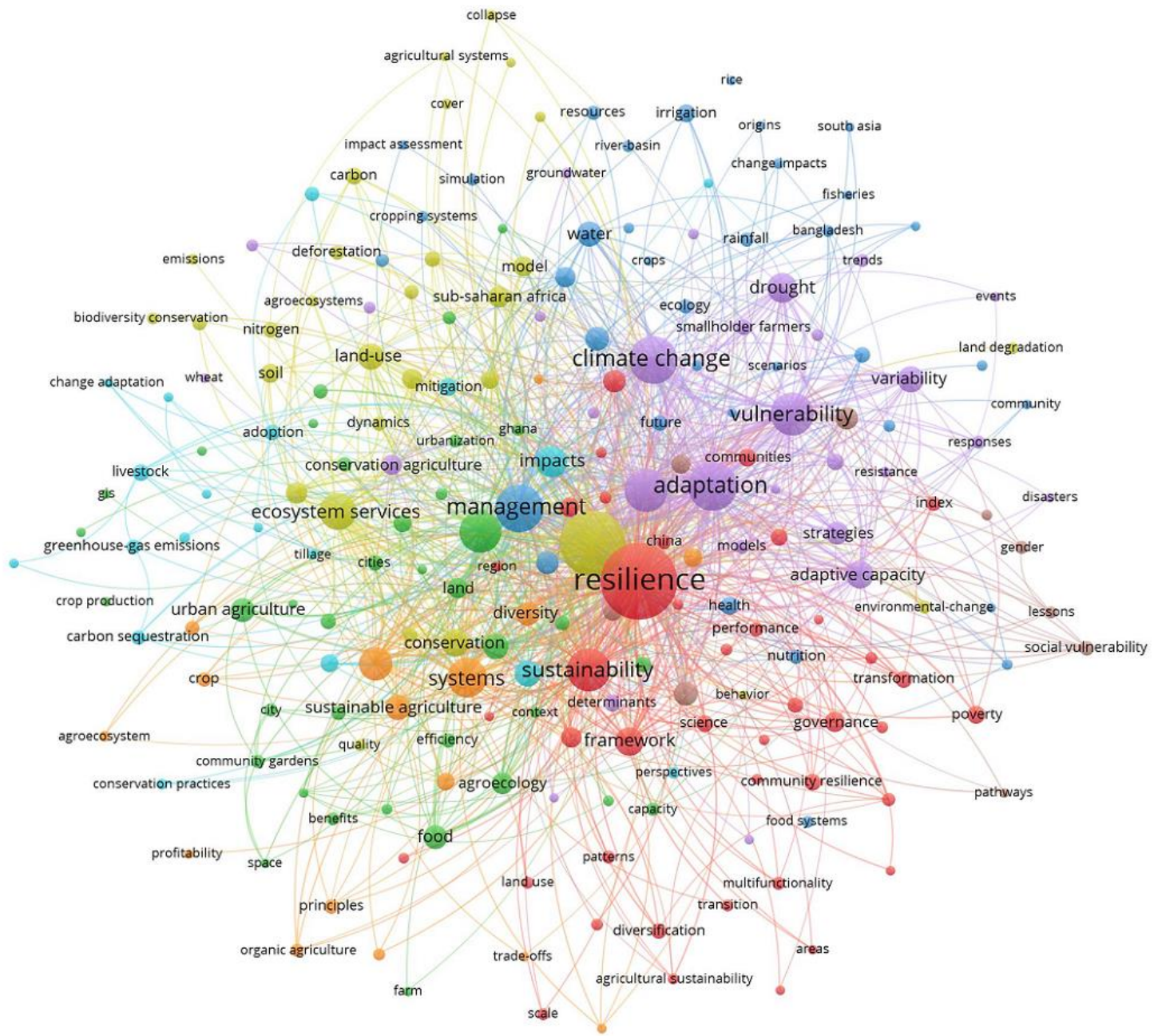

Figure 5. Co-occurrence of keywords in publications on economic resilience in the domain of agriculture in 1990-2020 
that both these journals are published by the same Elsevier publisher. The third cluster (yellow one) is led by a second most cited journal in all disciplines - Science (ISSN: 0036-8075). In this network it shows a total link strength of 26951, number of links -255 and 601 citations. Heat map shows a quite high interconnectedness of red and yellow clusters indicating a corresponding scientific streams published in these publication sources. The fourth (violet color) cluster is dominated by the Proceedings of the National Academy of Sciences of the United States of America (ISSN: 0027-8424) with a total link strength of 26084 , total number of links -253 and 585 citations. It should be noted, that papers published in sources belonging to the violet cluster differ significantly from the articles published in sources of any other cluster, as they tend to focus more on anthropological subjects. The smallest cluster centers around the Climatic Change (ISSN: 0165-0009) journal with a total link strength of 15868, 248 links and 374 citations.

Keywords are considered to reveal the nature of the study and provide the initial and essential information about the research (Baker, 2004). The analysis of co-occurrence of keywords provide insights about the prevailing research directions of the investigated field (van Eck and Waltman, 2014). In order to better understand the development of the research directions on economic resilience in agriculture, we conducted a keyword co-occurrence analysis (Fig. $5)$. The keyword has to occur at least 5 times in scientific documents to be included into analysis.

Analyzing co-occurrence of keywords, one distinct cluster (violet color) containing such keywords as adaptation, vulnerability, climate change and vulnerability emerges. It means that these keywords appear together very frequently and indicate studies aimed at evaluating vulnerability and adaptive capacity of agriculture to climate change. Another distinct cluster, represented by the red color is centered around keywords occurring in research aimed at evaluating sustainability of agriculture or resilience under sustainability framework. A smaller cluster centered on biodiversity, systems and sustainable agriculture keywords can be distinguished. These studies are focused on maintaining the biodiversity of agriculture under the climate change conditions. All other clusters are too densely interconnected to allow drawing their borders and thus hinder a possibility of further analysis. It should be noted, that although the economic resilience in agriculture appears as a focal point of our research and the corresponding keywords were used, no clear cluster representing economic facet of resilience in agriculture was identified. This outcome not only indicates an obvious underrepresentation of economic resilience in agricultural research context, but also specifies a research area for the future investigations, as this scientific vacuum should be covered.

\section{Conclusions}

The study revealed that economic resilience in agriculture is a promising research area, since it is quite scarcely researched: both theoretically and empirically. Such a scientific vacuum impedes development of the overall agricultural resilience research, as economic resilience is considered to be an inseparable part of agricultural resilience concept (Chonabayashi, Jithitikulchai \& Qu, 2020) and is focal in a development of more sophisticated variations of agricultural resilience, such as climate-smart agriculture (Taylor, 2018).

It was found, that typically, researchers do not concentrate on the economic resilience of agriculture as on the focal research object, but do investigate it under the frameworks related to sustainability, climate change, soil or water management, institutional quality, food security or environmental management. Although these studies provide some additional scientific knowledge on economic resilience in agriculture, it lacks a holistic overarching approach which would be possible if economic resilience in agriculture would be considered as the main research object.

The sidelined position of the economic resilience within the overall agricultural resilience research framework, which is confirmed by a very high geographical concentration of related research, led to a situation, that although introduced quite a long time ago, this notion is still in a state of flux and differences in its definitions may lead to a misconception in research objectives in the area. Although there have already been some attempts to conceptualize resilience into an operational and measurable framework, the general consensus on what exactly economic resilience of agriculture means and what it encompasses has not been achieved yet. Quite a low interconnectedness of a research conducted by various separate research institutions hinders the knowledge transfer and slows down the progress in the development of research in economic resilience in agricultural domain.

The main suggestion for the future research directions is to put economic resilience of agriculture at the forefront of the research. Clear delineation of resilience and its differentiation from sustainability and vulnerability concepts are necessary. Going further, the relationships among different dimensions of resilience - absorption of a shock, adaptation to it and transformation after it - also need attention. Conceptualization of resilience into a measurable construct could boost its empirical research. Studies, directed to indication of factors increasing or hindering eco- 
nomic resilience in agriculture, could be especially fruitful. Progress in this area would help to speed up research in other related fields, such as climate-smart agriculture or vulnerability of rural populations in less developed countries as well.

\section{References}

1. ABANKINA I., FILATOVA L., NIKOLAYENKO, E., 2018,. Polarization of universities in the Central Federal District of Russia under reform, Journal of Applied Research in Higher Education, 10(4): 410429, DOI: 10.1108/JARHE-12-2017-0159.

2. ADNAN N., NORDIN, S. M., 2020, How COVID19 effect Malaysian paddy industry? Adoption of green fertilizer a potential resolution, Environment, Development and Sustainability, 23(6): 8089-8129, DOI: 10.1007/s10668-020-00978-6.

3. ALTIERI M. A., NICHOLLS C. I., 2017, The adaptation and mitigation potential of traditional agriculture in a changing climate, Climatic Change, 140(1): 33-45.

4. ALTIERI M. A., NICHOLLS C. I., HENAO A., LANA M. A., 2015, Agroecology and the design of climate change-resilient farming systems, Agronomy for sustainable development, 35(3): 869-890.

5. ANDERSON B., POESCHEL F., RUHS M., 2020, Covid-19 and Systemic Resilience: Rethinking the Impacts of Migrant Workers and Labour Migration Policies, SSRN Electronic Journal,

DOI: $10.2139 /$ ssrn.3690413.

6. BAKER P., 2004, Querying keywords: Questions of difference, frequency, and sense in keywords analysis, Journal of English Linguistics, 32(4): 346-359.

7. BÉNÉ C., 2020, Resilience of local food systems and links to food security - A review of some important concepts in the context of COVID-19 and other shocks, Food Security, 12(4): 805-822,

DOI: 10.1007/s12571-020-01076-1.

8. BERNUÉS A., RUIZ R., OLAIZOLA A., VILLALBA D., CASASÚS I., 2011, Sustainability of pasture-based livestock farming systems in the European Mediterranean context: Synergies and tradeoffs, Livestock Science, 139(1-2): 44-57.

9. BIGGS R., SCHLÜTER M., BIGGS D., BOHENSKY E. L., BURNSILVER S., CUNDILL G., WEST P. C., 2012, Toward principles for enhancing the resilience of ecosystem services, Annual Review of Environment and Resources, 37: 421-448,

DOI: 10.1146/annurev-environ-051211-123836

10. BOYACI-GÜNDÜZ C. P., IBRAHIM S. A., WEI O. C., GALANAKIS C. M., 2021, Transformation of the Food Sector: Security and Resilience during the COVID-19 Pandemic, Foods, 10(3): 497:

DOI: $10.3390 /$ foods 10030497 .

11. BOUGHTON D., GOEB J., LAMBRECHT I., MATHER D., HEADEY D. D., 2020, Strengthening smallholder agriculture is essential to defend food and nutrition security and rural livelihoods in Myanmar against the COVID-19 threat: Elements for a proactive response, The International Food Policy Research Institute, 2: 1-11, DOI: $10.2499 / \mathrm{p} 15738$ coll 2.133687

12. BRANDAO F., PAIO A., WHITELAW C., 2017 , Mapping mass customization, 35th International Conference on Education and Research in Computer Aided Architectural Design in Europe, Sapienza University of Rome: 417-424.

13. BUSCH L.M., LACY W.B., 2019, Science, agriculture, and the politics of research, Routledge.

14. CATTIVELLI V., RUSCIANO V., 2020, Social Innovation and Food Provisioning during Covid-19: The Case of Urban - Rural Initiatives in the Province of, Sustainability, 12(11): 4444,
DOI: $10.3390 /$ su12114444

15. CHAGNON M., KREUTZWEISER D., MITCHELL E. A., MORRISSEY C. A., NOOME D. A., VAN DER SLUIJS J. P., 2015, Risks of large-scale use of systemic insecticides to ecosystem functioning and services, Environmental Science and Pollution Research, 22(1): 119-134.

16. CHALLINOR A., WHEELER T., GARFORTH C., CRAUFURD P., KASSAM A., 2007, Assessing the vulnerability of food crop systems in Africa to climate change, Climatic change, 83(3): 381-399.

17. CHONABAYASHI S., JITHITIKULCHAI T., QU Y., 2020, Does agricultural diversification build economic resilience to drought and flood? Evidence from poor households in Zambia, African Journal of Agricultural and Resource Economics, 15(311-20201781): 65-80.

18. CLAPP J., MOSELEY W. G., 2020, This food crisis is different: COVID-19 and the fragility of the neoliberal food security order, The Journal of Peasant Studies, 47(7): 1393-1417, DOI: $10.1080 / 03066150.2020 .1823838$.

19. COLON C., 2016, Modeling economic resilience, Dynamical Systems [math.DS], Université Paris-Saclay (NNT: 2016SACLX098).

20. DA SILVA J.A.T., MEMON A.R., 2017, CiteScore: A cite for sore eyes, or a valuable, transparent metric?, Scientometrics, 111(1): 553-556.

21. DARNHOFER I., BELLON S., DEDIEU B., MILESTAD R., 2010, Adaptiveness to enhance the sustainability of farming systems. A review, Agronomy for Sustainable Development, 30(3): 545-555, DOI: 10.1051/agro/2009053.

22. DARNHOFER I., FAIRWEATHER J., MOLLER H., 2010, Assessing a farm's sustainability: insights from resilience thinking, International journal of agricultural sustainability, 8(3): 186-198.

23. DAVLEMBAYEVA D., PAPAGIANNIDIS S., ALAMANOS E., 2019, Mapping the economics, social and technological attributes of the sharing economy, Information Technology \& People, 33(3): 841872, DOI: 10.1108/itp-02-2018-0085.

24. DESHINGKAR P., 2012, Environmental risk, resilience and migration: implications for natural resource management and agriculture, Environmental Research Letters, 7(1): 015603.

25. DI GREGORIO D., 2017, Place-based business models for resilient local economies, Journal of Enterprising Communities: People and Places in the Global Economy, 11(1): 113-128, DOI: 10.1108/jec-02-2015-0016.

26. EUROPEAN COMMISSION, 2018, Proposal for a Regulation of the European Parliament and of the Council establishing rules on support for strategic plans to be drawn up by Member States under the Common agricultural policy (CAP Strategic Plans) and financed by the European Agricultural Guarantee Fund (EAGF) and by the European Agricultural Fund for Rural Development (EAFRD) and repealing Regulation (EU) No 1305/2013 of the European Parliament and of the Council and Regulation (EU) No 1307/2013 of the European Parliament and of the Council, $\{$ SEC(2018) 305 final $\}-\{$ SWD(2018) 301 final\}, Brussels, 1.6.2018 $\operatorname{COM}(2018) 392$ final 2018/0216 (COD).

27. FALLOON P., BETTS R., 2010, Climate impacts on European agriculture and water management in the context of adaptation and mitigation - the importance of an integrated approach, Science of the total environment, 408(23): 5667-5687.

28. FARRELL P., THOW A. M., WATE J. T., NONGA N., VATUCAWAQA P., BREWER T., SHARP M. K., FARMERY A., TREVENA H., REEVE E., 
ERIKSSON H., GONZALEZ I., MULCAHY G., EURICH J. G., ANDREW N. L., 2020, COVID-19 and Pacific food system resilience: opportunities to build a robust response, Food Security, 12(4): 783791, DOI: 10.1007/s12571-020-01087-y.

29. FERREIRA F. A., 2018, Mapping the field of artsbased management: Bibliographic coupling and cocitation analyses, Journal of Business Research, 85: 348-357.

30. FINDLAY J. Y., 2017, Mapping theory without argument structure, Journal of Language Modelling, 4(2): 293-338.

31. FOLKE C., CARPENTER S.R., WALKER B., SCHEFFER M., CHAPIN T., ROCKSTROM J., 2010, Resilience thinking: integrating resilience, adaptability and transformability, Ecology and Society, 15(4): 20.

32. GALANAKIS C. M., 2020, The food systems in the era of the coronavirus (COVID-19) Pandemic Crisis, Foods, 9(4): 523, DOI: 10.3390/foods9040523.

33. GIANNAKIS E., BRUGGEMAN A., 2017, Economic crisis and regional resilience: Evidence from Greece, Regional Science, 96(3): 451-476.

34. GIANNAKIS E., BRUGGEMAN A., 2020, Regional disparities in economic resilience in the European Union across the urban-rural divide, Regional Studies, 54(9): 1200-1213.

35. GRAU R., KUEMMERLE T., MACCHI L., 2013, Beyond 'land sparing versus land sharing': environmental heterogeneity, globalization and the balance between agricultural production and nature conservation, Current Opinion in Environmental Sustainability, 5(5): 477-483.

36. HABIB R., AFZAL M.T., 2019, Sections-based bibliographic coupling for research paper recommendation, Scientometrics, 119(2): 643-656.

37. HAQUE M. I., AHMAD S., AZAD M. S., 2020, Mapping of scientific literature on Islamic Economics, Banking and Finance 1955 to 2020, Library Philosophy and Practice: 19-46.

38. HENRY R., 2020, Innovations in agriculture and food supply in response to the COVID-19 pandemic, Molecular Plant, 13(8): 1095-1097, DOI: 10.1016/j.molp.2020.07.011.

39. HOLLING C.S., 1973, Resilience and stability of ecological systems, Annual Review of Ecology and Systematics 4: 1-23.

40. HU J., ZHANG Y., 2017, Discovering the interdisciplinary nature of Big Data research through social network analysis and visualization, Scientometrics, 112(1): 91-109.

41. IARIA A., SCHWARTZ C., WALDINGER F., 2018, Frontier knowledge and scientific production: Evidence from the collapse of international science, The Quarterly Journal of Economics, 133(2): 927-991, DOI: 10.1093/qje/qjx046

42. JAYARARNAN T.K., 2004, Coping with vulnerability by building economic resilience: the case of Vanuatu, Economic vulnerability and resilience of small states Msida, eds. Briguglio L., Kisanga E.J., University of Malta. Islands and Small States Institute \& The Commonwealth Secretariat: 135-148.

43. JÁMBOR A., CZINE P., BALOGH P., 2020, The Impact of the Coronavirus on Agriculture: First Evidence Based on Global Newspapers, Sustainability, 12(11): 4535, DOI: 10.3390/su12114535.
44. KERR W.A., 2020, The COVID-19 pandemic and agriculture: Short- and long-run implications for international trade relations, Canadian Journal of Agricultural Economics/ Revue Canadienne d'agroeconomie, 68(2): 225-229, DOI:10.1111/cjag.12230.

45. KOELLNER T., SCHOLZ R. W., 2008, Assessment of land use impacts on the natural environment, ment, The International Journal of Life Cycle Assessment, 13(1): 32 .

46. KUMAR A., MANGLA S. K., KUMAR P., SONG M., 2021, Mitigate risks in perishable food supply chains: Learning from COVID-19, Technological Forecasting and Social Change, 166: 120643.

47. LAL R., 2016, Soil health and carbon management, Food and Energy Security, 5(4): 212-222.

48. LIN B.B., 2011, Resilience in agriculture through crop diversification: adaptive management for environmental change, BioScience, 61(3): 183-193.

49. LIOUTAS E.D., CHARATSARI C., 2021, Enhancing the ability of agriculture to cope with major crises or disasters: What the experience of COVID-19 teaches us, Agricultural Systems, 187: 103023, DOI: $10.1016 / j$.agsy.2020.103023.

50. LIPPER L., MCCARTHY N., ZILBERMAN D., ASFAW S., BRANCA G., 2017, 2018, Climate Smart Agriculture: Building Resilience to Climate Change (Natural Resource Management and Policy, 52), 1 st ed. 2018 ed., Springer.

51. MACLEOD M., NAGATSU M., 2018, What does interdisciplinarity look like in practice: Mapping interdisciplinarity and its limits in the environmental sciences, Studies in History and Philosophy of Science A (67): 74-84.

52. MAISONBE M., GROSSETTI M., MILARD B., JEGOU L., ECKERT D., 2017, The global geography of scientific visibility: a deconcentration process (1999-2011), Scientometrics, 113(1): 479-493.

53. MARTIN R., SUNLEY P., 2015, On the notion of regional economic resilience: conceptualization and explanation, Journal of Economic Geography, 15 (1): $1-42$.

54. MICHLER J. D., BAYLIS K., ARENDS-KUENNING M., MAZVIMAVI K., 2019, Conservation agriculture and climate resilience, Journal of environmental economics and management, 93: 148-169.

55. MIETZNER M., 2010, Indonesia in 2009: electoral contestation and economic resilience, Asian Survey, 50(1): 185-194.

56. NORMAN D.W., 2002, The farming systems approach: A historical perspective, Presentation held at the 17th Symposium of the International Farming Systems Association in Lake Buena Vista, Florida, USA, 17-20 Nov. 2002.

57. PERRINGS C., 2006, Resilience and sustainable development, Environment and Development Economics, 11(4): 417-427.

58. PETETIN L., 2020, The COVID-19 crisis: An opportunity to integrate food democracy into post-pandemic food systems, European Journal of Risk Regulation, 11(2): 326-336, DOI: 10.1017/err.2020.40.

59. PIÑEIRO-CHOUSA J., LÓPEZ-CABARCOS M. Á., ROMERO-CASTRO N.M., PÉREZ-PICO A M., 2020, Innovation, entrepreneurship and knowledge in the business scientific field: Mapping the research front, Journal of Business Research, 115: 475485. 
60. PRETTY J., 2008, Agricultural sustainability: concepts, principles and evidence, Philosophical Transactions of the Royal Society B, Biological Sciences, 363(1491): 447-465.

61. REIDSMA P., EWERT F., LANSINK A. O., LEEMANS R., 2010, Adaptation to climate change and climate variability in European agriculture: the importance of farm level responses, European journal of agronomy, 32(1): 91-102.

62. REIDSMA P., EWERT F., OUDE LANSINK A., 2007, Analysis of farm performance in Europe under different climate and management conditions to improve understanding of adaptive capacity, Climate Change, 84: 403-422

63. RESILIENCE ALLIANCE, 2010, Assessing resilience in social-ecological systems: Workbook for practitioners, Version 2.0, http://www.resalliance. org/3871.php (05.08.2019).

64. RIDLEY W., DEVADOSS S., 2020, The Effects of COVID-19 on Fruit and Vegetable Production, Applied Economic Perspectives and Policy, 43(1): 329340, DOI: 10.1002/aepp.13107.

65. RODRIGUES R. R., GANDOLFI S., NAVE, A. G., ARONSON J., BARRETO T. E., VIDAL C. Y., BRANCALION P. H., 2011, Large-scale ecological restoration of high-diversity tropical forests in SE Brazil, Forest Ecology and Management, 261(10): 1605-1613.

66. ROSAS S.R., 2017, Group concept mapping methodology: Toward an epistemology of group conceptualization, complexity, and emergence, Quality \& Quantity, 51(3): 1403-1416.

67. SCHILLING J., FREIER K. P., HERTIG E., SCHEFFRAN J., 2012, Climate change, vulnerability and adaptation in North Africa with focus on Morocco, Agriculture, Ecosystems \& Environment, 156: $12-26$.

68. SHARMA R., SHISHODIA A., KAMBL, S., GUNASEKARAN A., BELHADI A., 2020, Agriculture supply chain risks and COVID-19: mitigation strategies and implications for the practitioners, International Journal of Logistics Research and Applications: 1-27, DOI: 10.1080/13675567.2020.1830049.

69. SIMELTON E., FRASER E. D., TERMANSEN M., FORSTER P. M., DOUGILL A. J., 2009, Typologies of crop-drought vulnerability: an empirical analysis of the socio-economic factors that influence the sensitivity and resilience to drought of three major food crops in China (1961-2001), Environmental Science \& Policy, 12(4): 438-452.

70. SINGHAL S., VATTA L., 2017, Impact of krishi vigyan kendra on adoption of improved agricultural production practices, International Journal of Science, Environment and Technology, 6(2), 993-1000.

71. SMITH P., OLESEN J. E., 2010, Synergies between the mitigation of, and adaptation to, climate change in agriculture, The Journal of Agricultural Science, 148(5): 543-552.

72. TAYLOR M., 2018, Climate-smart agriculture: what is it good for?, The Journal of Peasant Studies, 45(1): 89-107.

73. TENDALL D. M., JOERIN J., KOPAINSKY B., EDWARDS P., SHRECK A., LE, Q. B., SIX J., 2015, Food system resilience: defining the concept, Global Food Security, 6: 17-23.

74. THILMANY D., CANALES E., LOW S. A., BOYS K., 2020, Local Food Supply Chain Dynamics and Resilience during COVID-19, Applied Economic
Perspectives and Policy, 43(1): 86-104, DOI: 10.1002/aepp.13121.

75. THOMPSON J., SCOONES I., 2009, Addressing the dynamics of agri-food systems: an emerging agenda for social science research, Environmental science \& policy, 12(4): 386-397.

76. TIMILSINA B., ADHIKARI N., KAFLE S., PAUDEL S., GAUTAM D., 2020, Addressing impact of COVID-19 post pandemic on farming and agricultural deeds, Asian Journal of Advanced Research and Reports, 11(4): 28-35 DOI: $10.9734 / \mathrm{ajarr} / 2020 / \mathrm{v} 11 \mathrm{i} 430272$.

77. TORERO M., 2020, Without food, there can be no exit from the pandemic, Nature, 580(7805): 588-589, DOI: 10.1038/d41586-020-01181-3.

78. VAN ECK N.J., WALTMAN L., 2014, Visualizing bibliometric networks, Measuring scholarly impact: Methods and practice, eds. Ding Y., Rousseau R. \& Wolfram D, Springer: 285-320.

79. VAN RAAN A., 1996, Advanced bibliometric methods as quantitative core of peer review based evaluation and foresight exercises, Scientometrics, 36(3): 397-420.

80. VASILJEVIC Z., SAVIC B. 2013, Knowledge as a source of competitive advantage of the agricultural enterprises, Thematic Proceedings 'Sustainable Agriculture and Rural Development in Terms of the Republic of Serbia Strategic Goals Realization within the Danube Region-Achieving Regional Competitiveness', December: 816-832.

81. ZORZETTO R., RAZZOUK D., DUBUGRAS M. T. B., GEROLIN J., SCHOR N., GUIMARAES J. A., MARI, J.D.J., 2006, The scientific production in health and biological sciences of the top 20 Brazilian universities. Brazilian journal of medical and biological research, 39(12): 1513-1520, DOI: $10.1590 /$ S0100-879X2006005000040

82. WAAGE J. K., MUMFORD J. D., 2008, Agricultural biosecurity, Philosophical Transactions of the Royal Society B: Biological Sciences, 363(1492): 863-876.

83. WORSTELL J., 2020, Ecological Resilience of Food Systems in Response to the COVID-19 Crisis, Journal of Agriculture, Food Systems, and Community Development: $1-8$, DOI: 10.5304/jafscd.2020.093.015.

84. WORSTELL J., GREEN J., 2017 Eight qualities of resilient food systems: Toward a Sustainability/Resilience Index, Journal of Agriculture, Food Systems, and Community Development, 7(3): 23-41, DOI: 10.5304/jafscd.2017.073.001

85. ZAREI M., RAD A., 2020, Covid-19, challenges and recommendations in agriculture, Journal of the Botanical Research Institute of Texas, 2 (1): 12-15

86. YOUNGBLOOD M., LAHTI D., 2018, A bibliometric analysis of the interdisciplinary field of cultural evolution, Palgrave Communications, 4(1): 19.

87. ZIMMERER K. S., DE HAAN S., 2020, Informal food chains and agrobiodiversity need strengthening - not weakening - to address food security amidst the COVID-19 crisis in South America, Food Security, 12(4): 891-894, DOI: 10.1007/s12571-020-01088-x.

88. ŽIČKIENE A., VOLKOV A., BALEŽENTIS T., ŠTREIMIKIENĖ D., 2020, Integrating Behavior Into Regional Resilience Concept for Sustainable Growth: An Example of Agricultural Sector, Problemy Ekorozwoju/ Problems of Sustainable Development, 15(2): 61-73. 